\title{
PENGARUH MINAT DAN PENGETAHUAN TEORI TERHADAP KOMPETENSI MENULIS BAHAN AJAR BAHASA INDONESIA
}

\author{
Asniati $^{1}$ \\ Abd Rahman Rahim ${ }^{2}$ \\ Andi Sukri Syamsuri ${ }^{3}$ \\ ${ }^{1}$ SD IT AL Ishlah Kecamatan Turikale, Kabupaten Maros, Indonesia \\ ${ }^{2,3}$ Universitas Muhammadiyah Makassar, Indonesia \\ asnyrisky@gmail.com ${ }^{1)}$ \\ rahman@unismuh.ac.id ${ }^{2 *}$ \\ andhies@unismuh.ac.id ${ }^{3)}$
}

\begin{abstract}
Abstrak
Tujuan penelitian ini adalah memperoleh, menganalisis, dan mendeskripsikan data mengenai (1) Pengaruh minat menulis terhadap kompetensi menulis bahan ajar bahasa Indonesia guru SD IT AL Ishlah Kecamatan Turikale, Kabupaten Maros, (2) Pengaruh pengetahuan teori bahan ajar terhadap kompetensi menulis bahan ajar bahasa Indonesia guru SD IT AL Ishlah Kecamatan Turikale, Kabupaten Maros, (3) Pengaruh secara bersama minat menulis dan pengetahuan teori bahan ajar terhadap kompetensi menulis bahan ajar bahasa Indonesia guru SD IT AL Ishlah Kecamatan Turikale, Kabupaten Maros. Jenis penelitian ini adalah penelitian survei dengan teknik korelatif. Adapun populasi penelitian adalah seluruh guru guru SD IT AL Ishlah Kecamatan Turikale, Kabupaten Maros tahun pelajaran 2020/2021 berjumlah 24 orang dengan teknik pengambilan sampel adalah total sampling. Hasil penelitian ini menunjukkan bahwa (1) Terdapat pengaruh signifikan antara pengetahuan teori bahan ajar terhadap kompetensi menulis bahan ajar bahasa Indonesia SD IT AL Ishlah Kecamatan Turikale Kabupaten Maros, dengan besar pengaruh 59,70\%, (2) Terdapat pengaruh signifikan antara minat menulis bahan ajar terhadap kompetensi menulis bahan ajar bahasa Indonesia SD IT AL Ishlah Kecamatan Turikale, Kabupaten Maros dengan besar pengaruh 55,29\%. (3) Terdapat pengaruh signifikans secara bersam-sama pengetahuan teori bahan ajar dan minat menulis bahan ajar terhadap kompetensi menulis bahan ajar bahasa Indonesia SD IT AL Ishlah Kecamatan Turikale, Kabupaten Maros dengan besar pengaruh 59,66\%.
\end{abstract}

Kata Kunci: Pengrtahuan Teori, Minat, Kompetensi menulis bahan ajar

Published by:

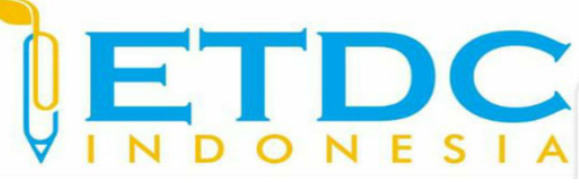

Copyright (C) 2021 The Author (s)

This article is licensed under CC BY 4.0 License

(cc) $\mathrm{BY}$ 


\section{PENGARUH MINAT DAN PENGETAHUAN TEORI TERHADAP KOMPETENSI MENULIS BAHAN AJAR BAHASA INDONESIA}

\section{Pendahuluan}

Peraturan Pemerintah Nomor 21 Tahun 2016 tentang Pelaksanaan Standar Isi dan Standar Kelulusan, keterlibatan guru dalam kurikulum tidak sebatas pada pelaksanaannya dalam bentuk kegiatan pembelajaran, akan tetapi guru bersama dengan stakeholder lainnya di sekolah itu juga menjadi penyusun kurikulum yang berlaku pada sekolah tempat mengajarnya. Rumusan ini sesuai dengan pendapat Popham dan Baker (201) yang mengatakan bahwa guru bukan hanya berkiprah sebagai pelaksana kurikulum yang andal, melainkan juga guru sebagai pembina dan pengontrol kurikulum. Dengan peran tersebut, guru seharusnya melakukan evaluasi secara kontinyu terhadap muatan kurikulum yang dijadikan acuan dalam proses pembelajaran. Lebih lanjut Danim (2017) berpendapat bahwa pemantauan program pembelajaran merupakan salah satu peran baru guru agar terhindar dari deviasi terhadap standar yang telah dibuat.

Berkenaan dengan peran guru, Sukmadinata (2011) mengemukakan bahwa guru adalah perencana, pelaksana, dan pengembang kurikulum yang terdepan. Guru diberi kesempatan untuk memilih dan mengembangkan materi standar dan kompetensi dasar sesuai dengan kondisi dan kebutuhan sekolah. Sebagai pengembang kurikulum, sangat pantas jika guru harus memiliki kompetensi profesional baik secara konseptual maupun operasional untuk melaksanakan proses pembelajaran yang aktif, kreatif, dan efektif.

Salah satu kompetensi yang harus diemban guru dalam praktik pembelajaran yaitu kompetensi menulis bahan ajar. Peraturan Pemerintah (PP) Republik Indonesia Nomor 19 Tahun 2005 Pasal 20 menyatakan bahwa rencana pembelajaran mencakup silabus dan RPP yang selanjutnya diatur dalam Peraturan Menteri Pendidikan Nasional (Permendiknas) Nomor 36 Tahun 2018 tentang Standar Proses. Salah satu komponen rencana pembelajaran yang memegang peranan penting dari keseluruhan isi kurikulum adalah materi ajar. Pendidik harus mampu memilih dan menyiapkan materi ajar sesuai prinsip pengembangannya agar peserta didik dapat mencapai kompetensinya. Menulis bahan ajar sebelum guru memulai kegiatan pembelajaran adalah sangat penting. Bahan ajar merupakan suatu bukti adanya kesiapan (readiness) guru untuk membelajarkan siswa.

Sumber belajar, materi esensil, dan tujuan sebagai bagian dari sistem pembelajaran, harus dirancang dengan baik menjadi bahan kegiatan pembelajaran. Proses pembelajaran perlu 
dirancang agar dapat mengakomodasi tipe-tipe belajar siswa yang berbeda-beda. Sanjaya (2008) mengatakan bahwa bahan pelajaran harus dikemas untuk menyesuaikan dengan tujuan yang harus dicapai seperti yang tercantum dalam kurikulum. Sudah menjadi pengetahuan umum bahwa guru-guru mengajar termasuk mata pelajaran Bahasa Indonesia mengandalkan buku-buku teks terbitan yang tampil dengan berbagai desain menarik yang sesuai dengan standar isi. Apalagi, buku-buku yang dimaksud cukup tersedia di sekolah karena didukung dana BOS (Biaya Operasional Sekolah). Boleh jadi karena kondisi demikian, guru kurang berminat untuk menulis bahan ajar. Padahal, dengan bahan ajar dapat berfungsi sebagai pencerahan kembali materi, kendali terhadap materi-materi yang tidak esensil, kontrol terhadap muatan kompetensi dasar, dan memudahkan siswa menguasai kompetensi tertentu.

Berdasarkan pemaparan di atas, jelas bahwa bahan ajar merupakan salah satu kompetensi guru yang harus dikuasai sebagai bagian yang tidak terpisahkan dengan pencapaian standar kompetensi menurut standar isi sebagaimana yang tercantum oleh BSNP (Badan Standar Nasional Pendidikan). Ketika guru menyusun bahan ajar berarti guru melakukan penyesuaian-penyesuaian terhadap komponen-komponen yang membentuk sistem pembelajaran. Hal ini dimaksudkan agar komponen-komponen tersebut saling berinteraksi dan berinterelasi untuk memudahkan siswa mencapai tujuan. Dengan maksud tersebut, guru dituntut untuk mampu menulis bahan ajar agar dapat membelajarkan siswa sesuai dengan potensi yang dimilikinya. Dalam kaitan inilah sehingga diperlukan suatu kajian tentang kompetensi guru Bahasa Indonesia dalam menulis bahan ajar dengan seluruh problematikanya. Tentu saja dengan maksud agar pola pembinaan dalam pembuatan bahan ajar guru dilakukan berdasarkan temuan dalam penelitian. Oleh karena itu, penelitian ini akan berupaya mendeskripsikan pengaruh minat menulis dan pengetahuan tentang konsep bahan ajar terhadap kompetensi menulis bahan ajar bahasa Indonesia guru SD IT AL Ishlah Kecamatan Turikale Kabupaten Maros.

\subsection{Konsep Pembelajaran Bahasa}

Pembelajaran bahasa Indonesia disesuaikan dengan tuntutan kompetensi dasar dan standar kompetensi yang telah ditentukan. Menurut peraturan pemerintah nomor 19 tahun 2005 tentang Standar Nasional Pendidikan dijelaskan bahwa seorang pendidik harus memiliki kompetensi sebagai agen pembelajaran, yakni (a) kompetensi paedagogik, (b) kompetensi sosial, (c) kompetensi kepribadian dan (d) kompetensi profesional. Secara umum tujuan pembelajaran bahasa Indonesia dinyatakan dalam kurikulum 2013 (Kemdikbud, 2013) adalah sebagai berikut: Siswa menghargai dan membanggakan bahasa dan sastra Indonesia sebagai bahasa persatuan (nasional) dan bahasa negara, Siswa memahami bahasa dan sastra Indonesia 
dari segi bentuk, makna, dan fungsi, serta mengunakannya dengan tepat dan kreatif untuk macam-macam tujuan, keperluan, dan keadaan, Siswa memiliki kemampuan menggunakan bahasa dan sastra Indonesia untuk meningkatkan kemampuan intelektual, kematangan emosional dan kematangan sosial, Siswa memiliki disiplin dalam berfikir dan berbahasa (berbicara dan menulis), Siswa dapat menikmati dan memanfaatkan karya satra untuk mengembangkan kepribadian, memperluas wawasan kehidupan, serta meningkatkan pengetahuan dan kemampuan berbahasa, dan Siswa menghargai dan membanggakan satra Indonesia sebagai khasanah budaya dan intelektual Indonesia.

\subsection{Hakikat Kompetensi Menulis Bahan Ajar}

Dalam arti fleksikal, kompetensi bersinonim dengan kemampuan. Gulo (Sanjaya (2012) membedakan kemampuan menjadi dua secara garis besar yaitu kemampuan yang tampak dan kemampuan yang tidak tampak. Kemampuan yang tampak disebut performance atau penampilan. Johnson (Sanjaya, 2012) menyatakan “Competency as rational performance which satisfactorily meets the objective for a desired condition". Suatu kompetensi ditunjukkan oleh penampilan atau unjuk kerja yang dapat dipertanggungjawabkan secara rasional dalam upaya mencapai suatu tujuan. Dengan demikian, suatu kompetensi dtunjukkan oleh penampilan atau unjuk kerja seseorang yang dapat dipertanggungjawabkan secara rasional dalam upaya mencapai suatu tujuan. Seseorang yang profesional tidak ditunjukkan dengan "kata-kata", melainkan dengan perbuatan. Jadi, profesionalisme itu merupakan komitmen para anggota suatu profesi untuk meningkatkan kemampuan profesionalnya dan secara terus-menerus mengembangkan strategi yang digunakannya dalam melakukan pekerjaan sesuai dengan profesinya itu (Danim, 2017).

Berdasarkan uraian di atas, kompetensi menulis bahan ajar merupakan salah satu indikator dari kompetensi profesional, karena kompetensi profesional berkenaan dengan profesional dan pengalaman mengajar guru. Hal ini diperkuat oleh pendapat Supratno (Trianto, 2010) menyebutkan bahwa salah satu subkompetensi profesional yaitu menguasai struktur dan materi kurikulum bidang studi. Khususunya dalam proses pembelajaran Bahasa Indonesia, Sumardi (2010) mengatakan bahwa seorang guru dituntut untuk mampu mengembangkan bahan ajar agar siswa mampu berkomunikasi secara wajar. Oleh karena itu, pembelajaran Bahasa Indonesia diarahkan untuk meningkatkan kemampuan siswa dalam berkomunikasi dengan bahasa Indonesia baik secara lisan maupun tertulis sesuai dengan kompetensi yang termaktub dalam kurikulum. 


\subsection{Hakikat Bahan Ajar}

Materi pelajaran secara implisit termuat dalam kompetensi dasar yang harus diwujudkan secara eksplisit oleh guru yang akan membelajarkan siswa. Sanjaya (2012) bahkan mengatakan bahwa materi pelajaran (learning materials) adalah segala sesuatu yang menjadi isi kurikulum yang harus dikuasai oleh siswa sesuai dengan kompetensi dasar dalam rangka pencapaian stándar kompetensi setiap mata pelajaran dalam satuan pendidikan tertentu. Secara umum bahan ajar diartikan sebagai sejumlah perangkat yang disediakan guru agar siswa dapat belajar. Sudrajat (2019) mengemukakan bahwa bahan ajar adalah seperangkat materi yang disusun secara sistematis baik tertulis maupun tidak tertulis sehingga tercipta lingkungan atau suasana yang memungkinkan siswa dapat belajar.

Supriyadi (2013) mengemukakan tiga fungsi bahan ajar yang berkaitan dengan pembelajaran di sekolah. Ketiga fungsi yang dimaksud antara lain: Pedoman bagi guru yang akan mengarahkan semua aktivitasnya dalam proses pembelajaran, sekaligus merupakan substansi kompetensi yang seharusnya diajarkan/dilatihkan kepada siswanya, Pedoman bagi siswa yang akan mengarahkan aktivitasnya dalam proses pembelajaran dan dapat berbuat seperti apa yang seharusnya dipelajari/dikuasainya, dan Alat evaluasi pencapaian atau penguasaan hasil pembelajaran. Bahan ajar sebagai salah satu perangkat pembelajaran harus benar-benar dapat berfungsi memudahkan siswa melakukan kegiatan pembelajaran.

\subsection{Kriteria Pemilihan Bahan Ajar}

Terdapat tiga kriteria menurut Sudrajat (2019) yang perlu diperhatikan dan dikembangkan oleh guru dalam penyusunan bahan ajar adalah sebagai berikut: Relevan, materi pembelajaran memiliki keterkaitan dengan standar, kompetensi dan komptensi dasar, Cukup, materi yang diajarkan cukup memadai dalam membantu siswa menguasai komptensi dasar yang diajarkan. Agar informasi yang disampaikan guru lebih bermakna bagi siswa, maka Sanjaya (2012) memberi empat kriteria yang perlu diperhatikan guru antara lain: Novelty, Proximity, Conflict, dan Humor.

\subsection{Hakikat minat menulis}

Menurut Kamus Bahasa Indonesia (KBBI) online dinyatakan bahwa minat adalah perhatian kesukaan, atau kecenderungan hati kepada sesuatu, atau suatu keinginan. Dalam minat terdapat unsur aktif, seperti yang dikemukakan oleh Sareb (2008), yaitu minat merupakan usaha aktif menuju kepada pelaksanaan suatu tujuan, karena tujuan itu pada umumnya merupakan titik akhir daripada gerakan menuju ke suatu arah untuk melaksanakan tujuan itu sendiri sehingga merupakan usaha dari pelaksanaan suatu tujuan. Pengertian lain ditulis oleh Slameto (2011) bahwa minat merupakan suatu rasa lebih suka dan rasa ketertarikan kepada 
suatu hal atau objek, atau aktivitas tanpa ada yang menyuruh. Adapun pandangan lain tentang minat dijelaskan oleh Suryabrata (2011); Mahmud (2010); Soemanto (2012) bahwa "Minat adalah perangkat mental yang dapat mengarahkan seseorang untuk sampai pada suatu pilihan”. Keberadaan minat seseorang dan kekuatannya hanya dapat dideteksi apabila sudah terwujud dalam bentuk perasaan atau sikap.

Kajian mengenai penulisan bahan ajar oleh guru sudah dilakukan oleh beberapa peneliti terdahulu. Hal ini menjadi bahan perbandingan atau penguatan terhadap kajian dalam penelitian ini. Hasil penelitian Hafid (2017) menyimpulkan bahwa terdapat pengaruh pelaksanaan motivasi motivasi guru (X1) terhadap kinerja guru (Y) secara signifikans. Demikian pulan, terdapat pengaruh kompetensi guru (X2) terhadap kinerja guru (Y) secara signifikan. Purwahida (2018) menyimpulkan bahwa pengembangan modul pembelajaran baca tulis anak usia sekolah dasar berhasil karena peserta dapat menyusun modul meskipun dalam bentuk sederhana. Handayani (2021) menyimpulkan bahwa guru sudah membuat bahan ajar, walaupun bahan ajar yang dibuat masih belum sempurna. Bahan ajar tersebut dapat membantu peserta didik belajar dengan mudah dan mandiri di Kota Pontianak. Beberapa hasil penelitian tersebut di atas umumnya menyatakan deskripsi kemampuan guru dalam membuat bahan ajar, namun blum dilihat aspek yang mempengaruhinya, misalnya motivasi, pengetahuan, dan sebagainya. Inilah yang membedakan penelitian ini dengan penelitian terdahulu.

Berdasarkan beberapa permasalahan di atas, penelitian ini merumuskan tujuan penelitian sebagai berikut:

1. Adakah pengaruh minat menulis terhadap kemampuan menulis bahan ajar bahasa Indonesia guru SD IT AL Ishlah Kecamatan Turikale, Kabupaten Maros?

2. Adakah pengaruh pengetahuan teori bahan ajar terhadap kompetensi menulis bahan ajar bahasa Indonesia guru SD IT AL Ishlah Kecamatan Turikale, Kabupaten Maros?

3. Adakah pengaruh secara bersama minat menulis dan pengetahuan teori dan pengetahuan teori bahan ajar terhadap kompetensi menulis bahan ajar bahasa Indonesia guru SD IT AL Ishlah Kecamatan Turikale, Kabupaten Maros?

\section{Metode Penelitian}

Penelitian ini adalah penelitian kuantitaf. Penelitian berusaha menggambarkan kondisi dan objek penelitian secara apa adanya sebagai pembuktian pengaruh dari variabel dengan variabel lainnya (Sugiyono, 2013). Penelitian ini didesain dengan penelitian korelasional regresif yang berupaya melihat pengaruh variabel X1 dan X2 terhadap variabel $\mathrm{Y}$ yaitu pengaruh minat menulis dan pengetahuan teori bahan ajar terhadap kompetensi menulis bahan 
ajar bahasa Indonesia guru SD IT AL Ishlah KecamatanTurikale, Kabupaten Maros. Penelitian ini dilakukan di SD IT AL Ishlah Kecamatan Turikale Kabupaten Maros, Provinsi Sulawesi Selatan. Populasi atau subjek dalam penelitian ini adalah seluruh guru SD IT AL Ishlah Kecamatan Turikale Kabupaten Maros tahun pelajaran 2020/2021. Karena jumlah populasi penelitian ini sedikit, maka seluruh populasi dijadikan subjek penelitian (total sampling). Jadi seluruh populasi menjadi objek penelitian (24 orang).

Pengumpulan data dalam penelitian ini dikumpulkan melalui tiga teknik yaitu: Teknik tes untuk mengukur unuk mengukur pemahaman teori bahan ajar guru. Teknik nontes (angket) untuk mengukur minat menulis bahan ajar guru. Teknik dokumentasi untuk menilai kompetensi membuat bahan ajar sesuai bahan ajar bahansa Indonesia yang telah dibuat guru (dokumen bahan ajar guru).

Analisis data dalam penelitian ini melalui beberapa tahapan yaitu, teknik persentase untuk analais data minat menulis bahan ajar bahasa Indonesia dan pengetahuan tentang konsep bahan ajar bahasa Indonesia guru SD IT AL Ishlah Kecamatan Turikale Kabupaten Maros dengan rumus: n/Nx100 untuk rentang 10-100. Analisis inferensial untuk menganalisis pengaruh varibal bebas terhadap bariabel terkat menggunakan teknik uji regresi sederhaan dan linier/ganda dengan fasilitas komputer. Analisis regresi linear berganda prinsipnya sama dengan analisis regresi linear sederhana, hanya variabel bebasnya lebih dari satu buah. Persamaan umumnya adalah: $\mathrm{Y}=\mathrm{a}+\mathrm{b}_{1} \mathrm{X}_{1}+\mathrm{b}_{2} \mathrm{X}_{2}$.

\section{Hasil dan Pembahasan}

\subsection{Hasil Penelitian}

Adapun data yang dianalisis adalah hasil tes pengetahuan teori bahan ajar, angket minat menulis bahan ajar, dan kompetensi menulis bahan ajar bahasa Indonesia guru SD IT AL Ishlah Kecamatan Turikale Kabupaten Maros. Untuk lebih jelasnya diuraikan sebagai berikut.

\section{Tingkat pengetahuan teori bahan ajar}

Berdasarkan nilai konversi, tingkat pengetahuan teori bahan ajar guru SD IT AL Ishlah Kecamatan Turikale Kabupaten Maros dapat dilihat pada tabel 1 berikut.

Tabel 1. Statistik nilai pengetahuan teori bahan ajar guru

\begin{tabular}{cc}
\hline Statistik & Nilai Statistik \\
\hline Subjek & 24 \\
Nilai Ideal & 100 \\
Nilai Tertinggi & 75 \\
Nilai Terendah & 57,1 \\
Nilai Rata-rata & 66,5 \\
\hline
\end{tabular}


Tabel 1 menunjukkan bahwa nilai rata-rata tingkat pengetahuan teori bahan ajar guru SD IT AL Ishlah Kecamatan Turikale Kabupaten Maros dengan subjek/responden penelitian 24 orang guru sebesar 66,5. Nilai yang dicapai responden tersebar dengan nilai tertinggi 75 dan nilai terendah 57,1 dari nilai tertinggi yang mungkin dicapai 100 dan nilai terendah yang mungkin dicapai 0 . Berdasarkan kategorisasi di atas, maka dinyatakan bahwa nilai pengetahuan teori bahan ajar guru SD IT AL Ishlah Kecamatan Turikale Kabupaten Maros berada pada kategori sedang.

\section{Tingkat minat menulis bahan ajar}

Berdasarkan nilai konversi, tingkat minat menulis bahan ajar guru SD IT AL Ishlah Kecamatan Turikale Kabupaten Maros dapat dilihat pada tabel 2 berikut.

Tabel 2. Statistik nilai pengetahuan teori bahan ajar guru

\begin{tabular}{cc}
\hline Statistik & Nilai Statistik \\
\hline Subjek & 24 \\
Nilai Konversi Ideal & 100 \\
Nilai Tertinggi & 61,8 \\
Nilai Terendah & 36,4 \\
Nilai Rata-rata & 49 \\
\hline
\end{tabular}

Tabel 2 menunjukkan bahwa nilai rata-rata tingkat minat menulis bahan ajar guru SD IT AL Ishlah Kecamatan Turikale Kabupaten Maros dengan subjek/responden penelitian 24 orang guru sebesar 49. Nilai yang dicapai responden tersebar dengan nilai tertinggi 61,8 dan nilai terendah 36,4 dari nilai tertinggi yang mungkin dicapai 100 dan nilai terendah yang mungkin dicapai 0. Berdasarkan kategorisasi, maka dinyatakan bahwa nilai minat menulis bahan ajar SD IT AL Ishlah Kecamatan Turikale Kabupaten Maros berada pada kategori rendah.

\section{Tingkat kompetensi menulis bahan ajar bahasa Indonesia}

Berdasarkan nilai konversi, tingkat kompetensi menulis bahan ajar bahasa Indonesia guru SD IT AL Ishlah Kecamatan Turikale Kabupaten Maros dapat dilihat pada tabel 3 berikut.

Tabel 3. Statistik nilai kompetensi menulis bahan ajar guru

\begin{tabular}{cc}
\hline Statistik & Nilai Statistik \\
\hline Subjek & 24 \\
Nilai Konversi Ideal & 100 \\
Nilai Tertinggi & 72,5 \\
Nilai Terendah & 37,5 \\
Nilai Rata-rata & 51,1 \\
\hline
\end{tabular}


Tabel 3 menunjukkan bahwa nilai rata-rata tingkat minat menulis bahan ajar guru SD IT AL Ishlah Kecamatan Turikale Kabupaten Maros dengan subjek/responden penelitian 24 orang guru sebesar 51,1. Nilai yang dicapai responden tersebar dengan nilai tertinggi 72,5 dan nilai terendah 37,5 dari nilai tertinggi yang mungkin dicapai 100 dan nilai terendah yang mungkin dicapai 0. Berdasarkan kategorisasi, maka dinyatakan bahwa nilai kompetensi menulis bahan ajar bahasa Indenesia SD IT AL Ishlah Kecamatan Turikale Kabupaten Maros berada pada kategori rendah.

\section{Pengujian Hipotesis (variabel $\mathrm{X} 1$ terhadap $\mathrm{Y}$ )}

Untuk menentukan ada-tidaknya pengaruh antara variabel X1 terhadap Y (pengetahuan teori bahan ajar guru terhadap kompetensi menulis bahan ajar bahasa Indonesia), maka data dari kedua variabel dianalisis menggunakan komputer program Add-Ins Analysis ToolPak of Excel. Adapun hasil analisis regresi variabel dikemukakan ringkasan hasil analisis data pada tabel 4 sebagai berikut.

Tabel 4. Hasil analisis regresi variabel X1 terhadap Y

\begin{tabular}{ccccc}
\hline & Coefficients & $\begin{array}{c}\text { Standard } \\
\text { Error }\end{array}$ & t Stat & P-value \\
\hline $\begin{array}{c}\text { Intercept } \\
\text { Pemahaman teori } \\
\text { bahan ajar (X1) }\end{array}$ & 29,78586 & 9,50299 & 3,134367 & 0,00897 \\
\hline
\end{tabular}

Dari tabel 4 di atas dikemukakan:

Hipotesis:

alpha $\quad:(0,05)$

P-value : 0,00897

Kriteria uji $\quad$ : Ho ditolak jika jika $P$-value $<$ alpha $(0,05)$

Keputusan $\quad$ : Ho ditolak jika karena $P$-value $(0,00897)<$ alpha $(0,05)$

Kesimpulan : kesimpulan bahwa terdapat pengaruh signifikan antara variabel pemahaman teori bahan ajar terhadap kompetensi menulis bahan ajar bahasa Indonesia guru SD IT AL Ishlah Kecamatan Turikale Kabupaten Maros.

Berdasarkan hasil ringkasan koofisien determinasi, dapat diperoleh nilai RSquare: 0,43524 yang artinya bahwa variabel pemahaman teori bahan ajar mempengaruhi kompetensi menulis bahan ajar bahasa Indonesia $43,524 \%$, sisanya dipengaruhi oleh variabel lain yang tidak dibahas.

\section{Pengujian Hipotesis (variabel $X 2$ terhadap $Y$ )}

Untuk menentukan ada-tidaknya pengaruh antara variabel X2 terhadap Y (minat 
menulis bahan ajar terhadap kompetensi menulis bahan ajar bahan ajar bahasa indonesia), maka data dari kedua variabel dianalisis dengan menggunakan komputer program Add-Ins Analysis ToolPak of Excel. Adapun hasil analisis regresi kedua variabel dikemukakan ringkasan hasil analisis data pada tabel 5 sebagai berikut.

Tabel 5. Hasil analisis regresi variabel X2 terhadap Y

\begin{tabular}{ccccc}
\hline & Coefficients & $\begin{array}{c}\text { Standard } \\
\text { Error }\end{array}$ & t Stat & P-value \\
\hline $\begin{array}{c}\text { Intercept } \\
\text { Minat menulis }\end{array}$ & $-5,72226$ & 1,381521 & $-4,142$ & 0,02627 \\
bahan ajar (X2) & 0,972 & 0,05079 & 19,13755 & $9,04 \mathrm{E}-15$ \\
\hline
\end{tabular}

Dari tabel 5 di atas dikemukakan:

Hipotesis:

$\begin{array}{ll}\text { alpha } & :(0,05) \\ \text { P-value } & : 0,02627\end{array}$

Kriteria uji $\quad$ : Ho ditolak jika jika P-value $<$ alpha $(0,05)$

Keputusan : Ho ditolak jika karena P-value $(0,022627)<$ alpha $(0,05)$

Kesimpulan : kesimpulan bahwa terdapat pengaruh signifikan antara variabel minat menulis bahan ajar terhadap kompetensi menulis bahan ajar bahasa Indonesia guru SD IT AL Ishlah Kecamatan Turikale Kabupaten Maros.

Berdasarkan hasil ringkasan koofisien determinasi dapat diperoleh nilai $R$ Square: 0,545771 yang artinya bahwa variabel pemahaman minat menulis bahan ajar mempengaruhi kompetensi menulis bahan ajar bahasa Indonesia 54,57\%, sisanya dipengaruhi oleh variabel lain yang tidak dibahas.

\section{Pengujian Hipotesis (variabel $\mathrm{X} 1$ dan $\mathrm{X} 2$ terhadap $\mathrm{Y}$ )}

Adapun ringkasan hasil analisis regresi pengaruh variabel kemampuan pemahaman teori bahan ajar dan minat menulis bahan ajar secara bersamasama/simultan terhadap kemampuan menulis abahan ajar bahasa Indonesia pada tabel 6 sebagai berikut.

Tabel 6. Hasil analisis regresi variabel X1 dan X2 terhadap Y

\begin{tabular}{lllll}
\hline & Coefficients & Standard Error & t Stat & P-value \\
\hline Intercept & $-7,02311$ & 3,055767 & $-2,29831$ & 0,032461 \\
\hline $\begin{array}{l}\text { Teori bahan ajar dan } \\
\text { minat menulis bahan } \\
\text { ajar (X1 dan X2) }\end{array}$ & 0,978117 & 0,053296 & 18,35241 & $5,54 \mathrm{E}-14$ \\
\hline
\end{tabular}


Dari tabel 6 di atas dikemukakan:

Hipotesis:

alpha $\quad:(0,05)$

P-value : :0,02627

Kriteria uji $\quad$ : Ho ditolak jika jika $P$-value $<$ alpha $(0,05)$

Keputusan : Ho ditolak jika karena $P$-value $(0,02627)<$ alpha $(0,05)$

Kesimpulan : kesimpulan bahwa terdapat pengaruh signifikans secara bersamsama pengetahuan teori bahan ajar dan minat menulis bahan ajar terhadap kompetensi menulis bahan ajar bahasa Indonesia guru SD IT AL Ishlah Kecamatan Turikale Kabupaten Maros.

Berdasarkan hasil ringkasan koofisien determinasi dapat diperoleh nilai Adjusted $R$ Square: 0,410263 yang artinya bahwa secara bersama-sama varaibel $\mathrm{X}_{1}$ (pengetahuan teori bahan ajar) dan variabel $\mathrm{X}_{2}$ (minat menulis bahan ajar ) mempengaruhi kompetensi menulis bahan ajar bahasa Indonesai 41,02\%, sisanya dipengaruhi oleh variabel lain yang tidak dibahas.

\subsection{Pembahasan}

Berdasarkan hasil pengolahan data, maka dapat diketahui bahwa pada analisis data tingkat pengetahuan teori bahan ajar SD IT AL Ishlah Kecamatan Turikale Kabupaten Maros, nilai rata-rata sebesar 66,10 , nilai tertinggi 88,33 dan nilai terendah 28,81 , dan berada pada kategori sedang. Analisis data tingkat minat menulis bahan ajar SD IT AL Ishlah Kecamatan Turikale Kabupaten Maros, nilai rata-rata sebesar 62,30, nilai tertinggi 85,71 dan nilai terendah 50,00 dan berada pada kategori sedang. Analisis data tingkat kompetensi menulis bahan ajar bahasa Indonesia SD IT AL Ishlah Kecamatan Turikale Kabupaten Maros, nilai rata-rata sebesar 63,33, nilai tertinggi 67,57 dan nilai terendah 53,91 dan berada pada kategori sedang.

Selanjutnya, berdasarkan pengujian hipotesis menunjukkan bahwa (1) terdapat pengaruh signifikan antara variabel pengeetahuan teori bahan ajar terhadap kompetensi menulis bahan ajar bahasa Indonesia SD IT AL Ishlah Kecamatan Turikale Kabupaten Maros, dengan besar pengaruh 59,70\%, (2) terdapat pengaruh signifikan antara variabel minat menulis bahan ajar terhadap kompetensi menulis bahan ajar bahasa Indonesia SD IT AL Ishlah Kecamatan Turikale Kabupaten Maros dengan besar pengaruh 55,29\%. (3) terdapat pengaruh signifikans secara bersam-sama pengetahuan teori bahan ajar dan minat menulis bahan ajar terhadap kompetensi menulis bahan ajar bahasa Indonesia SD IT AL Ishlah Kecamatan Turikale Kabupaten Maros dengan besar pengaruh 59,66\%.

Uraian di atas menunjukkan bahwa guru yang memiliki pengeetahuan teori bahan ajar 
berpengaruh terhadap tingginya kompetensi menulis bahan ajar bahasa Indonesia. Hasil penelitian ini sesuai dengan pandangan Sutejo (2015) menyatakan bahwa salah satu faktor kunci yang mempengaruhi kemampuan sesorang dalam mewujudkan kompetensi menulis adalah pemahaman tentang konsep tentang cara menulis dan latihan menulis secara kontinyu. Tentu saja hal ini sama halnya dengan menulis bahan ajar, membutuhkan pengetahuan atau konsep mengenai bahan ajar. Selain itu, faktor minat juga dominan karena merupakan penggerak yang mudah dalam aktivitas menulis. Semakin tinggi minat sesorang dalam menulis semakin muidah menggerakkan diri dalam aktivitas menulis. dan mudah menumbuhkan keterampilan menulis tersebut. Keinginan kuat untuk menulis bahan ajar berpengaruh terhadap kemampuan dan kualitas bahan ajar yang dibuat guru akan semakin baik. Hal di atas menguatkan konsep mengenai pentingnya teori yang dikemukakan oleh Sutanto (2015) bahwa, tidak bisa diabaikan teori sangat karena penting bagi suatu yang akan dikerjakan secara profesional. Kehadiran santa urgen. Tanpa teori, praktik hanya didasarkan atas alasan-alasan yang kebetulan. Sementara itu, menulis bahan ajar tidak sekadar coba-coba dalam pembentukannya, tetapi didasarkan pada konsep yang sudah dibangun sebagai sebuah aturan hakikatnya. Untuk itu, antara teori dan praktik harus menjadi dua sisi yang salaing menunjang. Teori merupakan panduan ilmiah untuk memudahkan terwujudnya suatu karya.

\section{Kesimpulan}

Berdasarkan rumusan masalah dan hasil penelitian yang didasarkan pada analisis data dan pengujian hipotesis maka dapat disimpulkan bahwa:

a. Terdapat pengaruh signifikan antara pengetahuan teori bahan ajar terhadap kompetensi menulis bahan ajar bahasa Indonesia SD IT AL Ishlah Kecamatan Turikale Kabupaten Maros, dengan besar pengaruh 59,70\%,

b. Terdapat pengaruh signifikan antara minat menulis bahan ajar terhadap kompetensi menulis bahan ajar bahasa Indonesia SD IT AL Ishlah Kecamatan Turikale Kabupaten Maros dengan besar pengaruh 55,29\%.

c. Terdapat pengaruh signifikans secara bersam-sama pengetahuan teori bahan ajar dan minat menulis bahan ajar terhadap kompetensi menulis bahan ajar bahasa Indonesia SD IT AL Ishlah Kecamatan Turikale Kabupaten Maros dengan besar pengaruh 59,66\%.

\section{DAFTAR PUSTAKA}

Ayuningtias, N., Asrial, A., \& Budiono, H. (2021). Pengembangan Bahan Ajar Video Interaktif Berbasis Youtube Tema 4 Subtema 2 pada Pembelajaran Daring di Kelas I Sekolah 
Dasar (Doctoral dissertation, Universitas Jambi).

Danim, S. (2017). Visi Baru Manajemen Sekolah. (Cetakan ke-2). Jakarta: Bumi Aksara.

Gie, L. (2013). Terampil Mengarang. Edisi I. Yogyakarta.

Hafid, M. (2017). Pengaruh motivasi dan kompetensi guru terhadap kinerja guru sekolah dan madrasah di lingkungan pondok pesantren Salafiyah Syafi'iyah Sukorejo. Jurnal Pendidikan Islam Indonesia, 1(2), 293-314.

Hamalik, O. (2013). Metode Belajar dan Kesulitan Kesulitan Belajar. Jakarta: Remaja Rosda karya.

Handayani, S., Halidjah, S., \& Ghasya, D. A. V. DESKRIPSI KEMAMPUAN GURU MEMBUAT BAHAN AJAR. Jurnal Pendidikan dan Pembelajaran Khatulistiwa, 10(3).

Mahmud. (2010). Psikologi Pendidikan. Bandung: Pustaka.

Mulyasa, E. (2011). Menjadi Guru Profesional. (Cetakan ke-7) Bandung: Remaja Rosdakarya.

Muntari, L. (2016). Pengembangan bahan ajar membaca Bahasa Indonesia untuk kelas V SD dengan model Dick dan Carey. Jurnal Media Didaktik, 2(2), 175-182.

Peraturan Pemerintah Nomor 19 Tahun 2005 tentang Standar Nasional Pendidikan

Popham, W., James., Baker., Eva L. (2017). Teknik Mengajar Secara Sistimatis. (Cetakan ke3). Jakarta: Rineka Cipta.

Pratiwi, Y. (2009). Beberapa Perspektif Teori Penyusunan Bahan Ajar Keterampilan Berbahasa Indonesia. Diksi, 16(2).

Purnono, P. I. D., Muthahar, S. M. C., br Tarigan, S. D., \& Susanto, R. (2020). Pengaruh Literasi Pedagogik Pendidik Terhadap Minat Belajar Siswa Di Sd Rabbaniyyun Islamic School. In Seminar Nasional Ilmu Pendidikan dan Multi Disiplin 3 (SNIPMD 3). ISBN: 978-6236566-35-0 (Vol. 3).

Purwahida, R. (2018). Problematika Pengembangan Modul Pembelajaran Baca Tulis Anak Usia Sekolah Dasar. Aksis: Jurnal Pendidikan Bahasa dan Sastra Indonesia, 2(1), 127-137.

Ridwan. (2014) . Pembinaan Kemampuan Menulis Bahasa. Indonesia. Jakarta: Putakan Press

Sanjaya, W. (2012). Perencanaan dan Desain Sistem Pembelajaran. (Cetakan ke-1). Jakarta: Kencana Prenada Media Group.

Slameto, (2011). Belajar dan Faktor-Faktor yang Mempengaruhinya, Jakarta,. Bina Aksara.

Soemanto, W. (2012). Psikologi Pendidikan. Bandung: Rosda karya.

Sudrajat, A. (2019). Kurikulum dan Pengembangan Bahan Ajar. Online (http://Kurikulumdanpembelajaran.Com). 
Sukmadinata, N. S. (2011). Kurikulum dan Pembelajaran Bandung: Remaja Rosdakarya.

Sumardi. (2010). Buku Pelajaran Bahasa Indonesia SD. Jakarta: Gramedia.

Supriyadi. (2013). Fungsi Bahan Ajar Online (http://Kurikulumdanpembelajaran. Com).

Suryabrata, S. (2011). Psikologi Kepribadian Jakarta; Rajawali Perss.

Suryaman, M. (2006). Dimensi-dimensi kontekstual di dalam penulisan buku teks pelajaran bahasa Indonesia. Jurnal Diksi, 12(2).

Sutanto, A. (2015). Menjadi Orang yang Profesional. Jakarta: Matakata

Sutarna, N., \& Lutfi, A. F. (2021). Bahan Ajar Berbasis Kearifan Lokal dan Budaya Untuk Meningkatkan Keterampilan Menulis Deskripsi. NATURALISTIC: Jurnal Kajian Penelitian Pendidikan dan Pembelajaran, 5(2b), 883-894.

Sutejo, H. (2015). Mengembangkan Keterampilan Menulis. Bandung: Muijahid Press.

Suttrisno, S., \& Puspitasari, H. (2021). Pengembangan Buku Ajar Bahasa Indonesia Membaca dan Menulis Permulaan (MMP) Untuk Siswa Kelas Awal. Tarbiyah Wa Ta'lim: Jurnal Penelitian Pendidikan dan Pembelajaran, 8(2), 83-91.

Suyitno, I. (2007). Pengembangan bahan ajar Bahasa Indonesia untuk Penutur Asing (BIPA) berdasarkan hasil analisis kebutuhan belajar. Wacana, 9(1), 62-78.

Tarigan, H. G. (2013). Menulis sebagai Suatu Keterampilan. Bandung: Angkasa

Trianto. (2010). Mendesain Pembelajaran Kontekstual di Kelas. (Cetakan ke-1) Jakarta: Prestasi Pustaka. 